\title{
Rzeczowniki męskoosobowe a rzeczowniki żeńskoosobowe. Glosy do praktyki
} leksykograficznej

Słowa kluczowe: maskulina, feminatywy, zakres znaczeniowy, definicja słownikowa, definiens.

doi: http://dx.doi.org/10.31286/JP.101.3.2

\section{Wprowadzenie}

We współczesnej polskiej rzeczywistości językowej (a dokładniej mówiąc: w sytuacjach użycia języka polskiego) wyraźnie już się zadomowiły nowe (tj. takie, które nieobecne są w definicyjnych słownikach języka polskiego) rzeczowniki żeńskoosobowe ${ }^{1}$, jak na przykład marszałkini (zob. Dyszak 2013; Zieniukowa 2013), i powstają kolejne takie feminatywy - wszystkie możliwe, a nawet kłopotliwe, na przykład ta ministra i ta doktora (zob. Breza 2013), by zastąpić tradycyjnie używane (w tej samej funkcji) rzeczowniki męskoosobowe ${ }^{2}$, gdyż - w przekonaniu zwolenników, a przede wszystkim zwolenniczek tej substytucji - stosowane dla nazwania kobiet maskulina są przejawem (rzekomego) seksizmu w języku ${ }^{3}$. Pełnej symetrii między obu wskazanymi klasami leksemów nie sposób jednak osiągnąć, czego (banalnymi, ale wyrazistymi) przykładami są chociażby takie najbardziej ogólne nazwy ludzi, jak człowiek czy osoba, z których każda cechuje się innym rodzajem gramatycznym (człowiek - r.m., osoba - r.ż.), ale jednej i drugiej można użyć do nazwania tych samych istot ludzkich bez względu na ich płeć (o kobiecie można powiedzieć osoba/człowiek i o mężczyźnie tak samo). Warto też w tym miejscu zwrócić uwagę na rzeczowniki męskoosobowe, które odnoszą się wyłącznie do mężczyzn, mimo że ich formy gramatyczne cechują końcówki rodzaju żeńskiego, jak chociażby na najbardziej reprezentatywny w tej grupie rzeczownik mężczyzna. Ten przykład pokazuje, że płeć osoby nazywanej danym rzeczownikiem nie musi być sygnalizowana przez jego formy

\footnotetext{
* dyszak@ukw.edu.pl; ORCID oooo-0oo2-2054-1192

1 Dalej nazywane też krótko feminatywami.

2 Dalej nazywane też krótko maskulinami.

3 Rzekomego, nikt bowiem celowo nie wprowadzał do języka maskulinów skierowanych przeciw kobietom. Nagminnie tworzone feminatywy prowadzą (moim zdaniem) do niepotrzebnej redundancji, są sprzeczne z ekonomicznością języka, a nawet fałszują obraz rzeczywistości pozajęzykowej. Celem nazwania na przykład kobiety kierującej ministerstwem ministrem, a kobiety, która przewodniczy obradom sejmu, marszałkiem (a więc za pomocą rzeczowników, których rodzaj gramatyczny jest określany jako męski), nie jest przekazanie informacji o ich płci (podobnie w wypadku nazywanych tymi samymi rzeczownikami mężczyzn), ale o kompetencjach/prerogatywach osoby (kobiety/mężczyzny) pełniącej jedną czy drugą funkcję.
} 
gramatyczne/fleksyjne (końcówki przypadkowe rzeczownika mężczyzna są zbieżne z końcówkami przypadków rzeczownika kobieta).

Poruszone tu tylko zjawisko ekspansji feminatywów we współczesnej polszczyźnie (o charakterze bardziej społecznym niż stricte językowym ${ }^{4}$ ) - mimo jego akceptacji także w środowisku językoznawców (zob. np. Kita 2013) - jest przykładem mieszania dwóch odrębnych (choć niewątpliwie związanych ze sobą) światów: (wewnątrz)językowego i pozajęzykowego, rzeczowniki żeńskoosobowe przeciwstawia się bowiem rzeczownikom męskoosobowym analogicznie do zróżnicowania płciowego ludzi ${ }^{5}$, a przecież wi ęks zość maskulinów (na co wskazują m.in. słownikowe definicje ich znaczeń) nie wyraża (prymarnie) płci nazywanych przez nie ludzi (są to rzeczowniki, które umownie można uznać za semantycznie „bezpłciowe” lub „dwupłciowe”, gdyż można ich użyć zarówno w odniesieniu do mężczyzn/chłopców, jak i do kobiet/dziewczyn), choć oczywiście w każdym wypadku te same rzeczowniki (ze względu na swój rodzaj gramatyczny) mogą być użyte do nazywania osób płci męskiej. Dlatego też w niniejszym artykule przedmiotem zainteresowania będą nie maskulina i feminatywy jako jednostki leksykalno-gramatyczne (opisywane szeroko i w artykułach, i w pracach monograficznych; por. Łaziński 2006 czy Nowosad-Bakalarczyk 2009), ale wspomniane wyżej słownikowe definicje ich znaczeń ${ }^{6}$. W tym celu analizie zostały poddane definicje zawarte w najnowszym, a tym samym najbardziej aktualnym (ciągle uzupełnianym i dającym możliwości wprowadzania w nim zmian) Wielkim słowniku języka polskiego PAN pod red. Piotra Żmigrodzkiego (dalej: wSJP PAN) ${ }^{7}$, które (lub sposoby ich konstruowania) w zależności od potrzeby będą porównywane z odpowiednimi definicjami w Uniwersalnym słowniku języka polskiego pod red. Stanisława Dubisza (dalej: USJP), a poczynione w tym zakresie spostrzeżenia stanowić będą tytułowe glosy do stosowanej (w nich i w ogóle) praktyki leksykograficznej.

\section{Rzeczowniki męskoosobowe}

\subsection{Maskulina, których definicje znaczeń nie specyfikują płci}

Definicje znaczeń rzeczowników męskoosobowych, które nie wskazują na płeć nazywanych nimi osób, konstytuowane są dwojako: 1) albo za pomocą definiensa o najbardziej ogólnym znaczeniu, 2) albo za pomocą jego hiponimu.

\footnotetext{
4 Feminatywy nie są zjawiskiem nowym i są obecne w języku od dawna, dotyczy to także neologizmów podobnych do tych, jakie pojawiają się dzisiaj (por. np. Dyszak 2020).

5 Nie neguję w ten sposób korelacji między formami gramatycznymi a płcią, która - jak wiadomo - jest „podstawą tradycyjnego rozróżnienia rodzaju gramatycznego i naturalnego" (Saloni, Świdziński 1985: 161; autorzy ci zwracają jednakże uwagę na „nieskuteczność wszelkich wyjaśnień «płciowych» charakterystyki rodzajowej”, tamże), i zdaję sobie sprawę, że korelacja ta w wypadku rzeczowników osobowych jest bardzo silna, co podkreśla Roman Laskowski (zob. Grzegorczykowa i in. 1984: 154).

6 Podstawą listy rzeczowników obu wymienionych klas (ograniczonej tu do wybranych przykładów) są feminatywy scharakteryzowane w moim wcześniejszym artykule (Dyszak 2016).

7 Jeśli cytowane w niniejszym artykule definicje (i maskulinów, i feminatywów) nie są w dodatkowy sposób oznaczone, to pochodzą z tego właśnie słownika (stosowane w nich wyróżnienia są moje - A.S.D.).
} 
W funkcji składnika formalnie konstytutywnego definicji pierwszego typu (1) dominuje wymieniony już wyżej rzeczownik osoba ('konkretny człowi ek - istota żywa's), por. np.:

komendant 1. o s o b a zajmująca stanowisko przełożonego niektórych instytucji w wojsku oraz w organizacjach działających na wzór wojskowy, 2. o s o b a dowodząca zorganizowaną grupą osób walczących, 3. o s o b a kierująca zorganizowaną grupą harcerzy.

Zdecydowanie rzadziej, co ciekawe, funkcję tę spełnia drugi ze wskazanych na wstępie rzeczowników semantycznie bezrodzajowych, a mianowicie człowiek ('is t o ta żywa, zdolna do mówienia, myślenia i tworzenia dóbr kultury ${ }^{\text {'9 }}$ ), por. np.:

kołtun pogard. czło wi ek ograniczony i mający wąskie horyzonty intelektualne.

Mniej liczne są też rzeczowniki męskoosobowe, których znaczenia definiuje się za pomocą także semantycznie bezrodzajowych peryfraz (jak ten, kto lub ktoś, kto), a ich znaczenia można sprowadzić do wspólnej formuły 'o s o b a, której mówiący nie określa dokładnie ${ }^{\text {'0 }}$, por. np.:

(a) następca ten, k to obejmuje jakieś stanowisko po kimś;

(b) obłudnik kt o ś, k to ukrywa swoje prawdziwe myśli i uczucia, aby przedstawić się w lepszym świetle.

Wskazane różnice między tymi czterema typami definicji znaczeń w pierwszej grupie omawianych maskulinów mają charakter czysto formalny, gdyż rzeczowniki osoba i człowiek oraz peryfrazy ten, kto i ktoś, kto (jako definiensy ich znaczeń) można uznać za synonimy ${ }^{11}$, na co wskazuje też możliwość wymiennego ich stosowania, por. na przykład definicje rzeczownika muzyk z użyciem każdego z wymienionych definiensów:

(a) muzyk o s o b a zajmująca się komponowaniem lub wykonywaniem utworów muzycznych ${ }^{12}$;

(b) muzyk czło w i ek zajmujący się komponowaniem lub wykonywaniem utworów muzycznych;

(c) muzyk ten, kto zajmuje się komponowaniem lub wykonywaniem utworów muzycznych;

(d) muzyk k to ś, k to zajmuje się komponowaniem lub wykonywaniem utworów muzycznych.

8 Zob. osoba 1. W WSJP PAN.

9 Zob. człowiek 1. W WSJP PAN.

10 Zob. kto II i ktoś 1 . W WSJP PAN.

11 Warto zwrócić uwagę na fakt, że znaczenia rzeczowników osoba i człowiek definiowane są m.in. za pomocą wyrażenia istota żywa (zob. wyżej). Mimo że w definicji znaczenia osoby pojawia się w funkcji definiensa rzeczownik człowiek, nie jest on hiperonimem dla definiendum. Między obydwoma rzeczownikami zachodzi relacja wzajemnej hiponimii, por. jeżeli ktoś jest osobą, to jest człowiekiem, i na odwrót: jeżeli ktoś jest człowiekiem, to jest osobą. Zgodnie z postulatem Macieja Grochowskiego (1993: 38): „tylko jedna spośród jednostek równoznacznych powinna zostać zdefiniowana, opis semantyczny drugiej natomiast powinien ograniczyć się do przytoczenia odsyłacza do pierwszej”.

12 Taką definicję zamieszczono w wSJP PAN, następne są wynikiem substytucji członu konstytutywnego. 
Przykładem dowolności (jeśli nie przypadkowości) stosowania (w funkcji definiensów) rzeczowników o znaczeniu ogólnym (osoba, człowiek) są też w WSJP PAN definicje znaczeń maskulinów z tego samego pola znaczeniowego, por. np.:

(a) nauczyciel 2. książk. o s o b a lub jakiś czynnik, z którymi kontakt sprawia, że ktoś nabywa pożądanych cech albo umiejętności;

(b) wychowawca 2. książk. c złowi ek, który kształtuje osobowość i umiejętności innych.

Możliwość wymiennego stosowania wskazanych wyżej definiensów pokazuje też porównanie definicji znaczeń (wybranych) rzeczowników męskoosobowych, które w obu wymienionych wcześniej słownikach są zdefiniowane z użyciem innego członu konstytutywnego ${ }^{13}$. Można w tym zakresie wskazać:

(1) rzeczowniki, których znaczenia zostały zdefiniowane w WSJP PAN za pomocą rzeczownika osoba, a w USJP w różny sposób, a mianowicie:

(a) za pomocą rzeczownika człowiek, np.: bezbożnik, bywalec, grzesznik, karzeł, okrutnik, psotnik, rówieśnik, równolatek, sadysta, samotnik;

(b) za pomocą peryfrazy ten, kto, np.: ofiarodawca, plotkarz, sprzedawca, uczeń, ulubieniec, władca, wszetecznik, złodziej;

(c) za pomocą peryfrazy ktoś, kto, np.: pomocnik (zn. $1^{14}$ ), rozrabiaka;

(2) rzeczowniki, których znaczenia zostały zdefiniowane w WSJP PAN za pomocą rzeczownika człowiek, a w USJP za pomocą rzeczownika osoba, np.: awanturnik (zn. $3^{15}$ ), złośnik;

(3) rzeczowniki, których znaczenia zostały zdefiniowane w WSJP PAN za pomocą peryfrazy ten, kto lub ktoś, kto, a w UsJP dwojako:

(a) za pomocą rzeczownika osoba, np.: niewolnik, samobójca;

(b) za pomocą rzeczownika człowiek, np.: krwiodawca, obłudnik.

Funkcję składnika formalnie konstytutywnego definicji drugiego typu (2) pełnią nazwy męskoosobowe o węższym zakresie znaczeniowym niż zakres rzeczownika człowiek i jego synonimów, ale oparte semantycznie na pojęciach ogólnych, wyrażanych w definicjach ich znaczeń na przykład rzeczownikiem osoba lub peryfrazą ten, kto, por.:

(a) aktywista bardzo aktywny c zło n e k jakiejś organizacji lub ruchu społecznego (zob. członek 2. o s ob a należąca do jakiejś organizacji politycznej, naukowej lub społecznej w wyniku osobistej decyzji lub z wyboru);

(b) aktor a r ty s t a odgrywający role w teatrze bądź filmie (zob. artysta 1. t e n, k to uprawia określoną dziedzinę sztuki).

13 Schematy definicji maskulinów, jakie występują w WSJP PAN, nie różnią się zasadniczo od tych, które zastosowano wcześniej w USJP. Tam wszakże obok form mianownikowych rzeczownika człowiek występuje w definicjach wyrażenie o człowieku (por. np. hasła bałwan 2., cygan 2., diabeł 2.b), a peryfraza ktoś, kto występuje także w formie zależnej o kimś, kto (por. np. hasło swawolnik) albo w jej pozycji pojawia się tylko forma miejscownika zaimka ktoś: o kimś (por. np. anioł 2.)

14 W UsJP por. zn. 1.

15 W USJP por. zn. 2. 
Można przypuszczać, że wybór sposobu definiowania danego rzeczownika męskoosobowego nie ma obiektywnych uwarunkowań (jest wynikiem przypadku, tradycji leksykograficznej, przyzwyczajeń leksykografów itd.), co szczególnie dobrze ilustrują definicje znaczeń maskulinów należących do tych samych pól znaczeniowych, por. np.:

(1) nazwy osób popełniających zbrodnie:

(a) definicja, w której użyto definiensa o najszerszym znaczeniu, np.:

ojcobójca o s o b a, która zabiła swojego ojca;

(b) definicja, w której użyto w funkcji definiensa hiponimu rzeczownika osoba, np.:

matkobójca zabó j ca własnej matki ${ }^{16}$ (zob. zabójca o s ob a, która popełniła zabójstwo);

(2) nazwy osób będących twórcami dzieł pisanych:

(a) definicja, w której użyto definiensa o najszerszym znaczeniu, np.:

komediopisarz o s o b a, która pisze komedie ${ }^{17}$;

(b) definicja, w której użyto w funkcji definiensa hiponimu rzeczownika osoba, np.:

dramatopisarz a u tor dramatów - utworów literackich przeznaczonych do wystawienia na scenie (zob. autor 1. o s o b a, która stworzyła jakieś dzieło).

W użyciu - jako definiensów - rzeczowników zabójca (zamiast frazy osoba, która zabiła) czy autor (zamiast frazy osoba, która piszeltworzy) można się dopatrywać dążenia do skrótowości, a w konsekwencji - do formalnej prostoty definicji znaczeń odpowiednich rzeczowników.

Możliwość wymiennego stosowania definiensów o znaczeniu ogólnym (takich jak rzeczownik osoba) i ich hiponimów potwierdza kolejne zestawienie definicji znaczeń zawartych W WSJP PAN z definicjami znaczeń tych samych rzeczowników, jakie zapisano w USJP, a które zawierają właśnie definiens osoba, por. na przykład twórca w zn. 2 w WSJP PAN ('ar tysta będący autorem dzieł w określonej dziedzinie sztuki') i twórca w zn. a) w USJP ('o s o b a, która coś tworzy, zwłaszcza w dziedzinie sztuki; artysta'). Z kolei niektóre maskulina definiowane w USJP za pomocą różnych hiponimów rzeczownika osoba w WSJP PAN definiowane są za pomocą tego właśnie definiensa, por. w obu słownikach definicje (odpowiednich) znaczeń takich maskulinów, jak choćby: baletmistrz ('reżyser i inscenizator') ${ }^{18}$, choreograf ('specjalista'), komendant (zn. 1 'zwierzchnik'), muzyk ('twórca lub wykonawca'), poset ('członek'), szef ('zwierzchnik'), uczeń (zn. 3 'zwolennik i kontynuator').

\subsection{Maskulina, których definicje znaczeń sugerują ich odniesienie tylko do mężczyzn}

W definicjach znaczeń rzeczowników męskoosobowych, które (zgodnie z tymi definicjami) można odnieść wyłącznie do osób płci męskiej, w funkcji definiensa pojawia się zawsze

16 Brak w wsJP PAN hasła dla odpowiedniego feminatywu matkobójczyni.

17 Podobnie pamiętnikarz.

$18 \mathrm{~W}$ nawiasach podaję rzeczowniki, które konstytuują odpowiednie definicje w USJP. 
rzeczownik mężczyzna ('o s oba dorosła płci męskiej'19) i sporadycznie występują - jako dodatkowe/alternatywne - rzeczowniki chłopiec lub chłopak ('niedorosły c złowiek płci męski ej' ${ }^{20}$, 'młody mężczyzna a' ${ }^{21}$ ), por. np.:

(a) fordanser męż c z y z n a, którego można wynająć do tańca;

(b) kolega 1. chłopiec lub mężczyzna, znany danej osobie z powodu wspólnej nauki, pracy, zabawy lub działalności w jakiejś organizacji;

(c) wybranek książk. ukochany mę ż c zy z n a lub chło pak.

Jednakże z porównania definicji znaczeń maskulinów definiowanych w ten właśnie sposób z odpowiednimi definicjami w USJP wynika, że można tworzyć definicje ich znaczeń także za pomocą definiensów niewskazujących na płeć nazywanej osoby, na przykład znaczenia rzeczownika masochista (w WSJP PAN zn. 1 i 2 'mężczyzna') w USJP są definiowane za pomocą rzeczownika osoba ${ }^{22}$, z kolei definicję znaczenia rzeczownika cwaniak (w WSJP PAN 'mężczyzna') konstytuuje w USJP rzeczownik człowiek, a do zdefiniowania znaczenia rzeczownika swat (w WSJP PAN zn. 1 'mężczyzna') użyto peryfrazy ten, kto. Sytuację odwrotną natomiast przynosi na przykład porównanie definicji znaczenia rzeczownika kabalarz, która w WSJP PAN jest konstytuowana przez rzeczownik osoba, a w USJP - za pomocą rzeczownika mężczyzna.

Także porównanie definicji znaczeń maskulinów definiowanych za pomocą rzeczownika mężczyzna z definicjami znaczeń innych rzeczowników, ale należących do tych samych pól znaczeniowych, pokazuje, że porównywanym rzeczownikom przypisano w WSJP PAN różne zakresy znaczeniowe:

(1) nazwy osób charakteryzujących się gwałtownym usposobieniem, por. np.:

(a) maskulinum, którego znaczenie jest zdefiniowane za pomocą rzeczownika mężczyzna:

cholernik 1. przest. męż c z y z n a, który łatwo wpada w złość

(definicja wskazuje, że ten rzeczownik można odnieść tylko do osób płci męskiej);

(b) maskulinum, którego znaczenie jest zdefiniowane za pomocą rzeczownika osoba:

awanturnik 1. o s o b a, która urządza awantury (gwałtowne kłótnie) lub ma do tego skłonność;

(c) maskulinum, którego znaczenie jest zdefiniowane za pomocą rzeczownika człowiek:

złośnik c złow i ek, który łatwo wpada w złość, przejawiającą się agresją wobec innych osób

(obie definicje w pkt b) i c) wskazują, że wymienione rzeczowniki można odnieść zarówno do mężczyzn, jak i do kobiet, więc nie jest jasne, dlaczego inną sugestię zawiera definicja znaczenia maskulinum cholernik);

19 Zob. mężczyzna 1. w WSJP PAN.

20 Zob. chłopiec 1. i chtopak 1. w WSJP PAN.

21 Zob. chłopiec 3. i chłopak 3. w WSJP PAN.

22 Rzeczownik ten jest też definiensem obu znaczeń sadysty w WSJP PAN, co różni odpowiednie definicje od definicji masochisty. 
(2) nazwy osób prowadzących rozwiązły tryb życia, por. np.:

(a) maskulinum, którego znaczenie jest zdefiniowane za pomocą rzeczownika mężczyzna: bezwstydnik męż czyz n a, który zachowuje się w sposób niezgodny z powszechnie przyjętymi normami związanymi z seksem i nagością

(ta definicja wskazuje, że bezwstydnikiem można nazwać jedynie osobę płci męskiej);

(b) maskulinum, którego znaczenie jest zdefiniowane za pomocą rzeczownika osoba:

rozpustnik 1. o s ob a, która dopuszcza się rozpusty - uważanego za niemoralne postępowania w sferze seksu ${ }^{23}$

(ta definicja wskazuje, że wymieniony rzeczownik można odnieść do każdej osoby bez względu na jej płeć, choć intuicja podpowiada, że kobiety nie nazwie się ani bezwstydnikiem, ani rozpustnikiem);

(3) nazwy osób grających na instrumentach muzycznych, por. np.:

(a) maskulinum, którego znaczenie jest zdefiniowane za pomocą rzeczownika mężczyzna:

harfista męż c z yz n a grający na harfie

(nazwa, której znaczenie zostało zdefiniowane tylko w odniesieniu do osób płci męskiej);

(b) maskulinum, którego znaczenie jest zdefiniowane za pomocą rzeczownika osoba:

lutnista o s o b a grająca na lutni ${ }^{24}$;

(c) maskulinum, którego znaczenie jest zdefiniowane za pomocą rzeczownika muzyk ('o s o b a zajmująca się komponowaniem lub wykonywaniem utworów muzycznych'):

flecista muzyk grający na flecie ${ }^{25}$

(wybór składnika kategoryzującego w każdej z definicji w pkt b) i c) sugeruje odniesienie obu odpowiednich maskulinów zarówno do mężczyzn, jak i do kobiet, jednakże w użyciach konkretnym i predykatywnym kobiety nie nazwie się ani lutnistą, ani flecistą, tak jak i nie nazwie się jej harfistą $\left.{ }^{26}\right)$.

Inaczej sytuacja przedstawia się na przykład w wypadku rzeczownika zakonnik, którego znaczenie zostało zdefiniowane za pomocą definiensa członek ('o s o b a należąca do jakiejś

23 Podobnie wszetecznik.

24 Podobnie wiolonczelista.

25 Podobnie fletnista i alcista (zob. zn. 1. i 2.). Rzeczownik alcista - jako jedyny spośród wymienionych tu maskulinów należących do tego samego pola znaczeniowego - został uznany za termin muzyczny, a dodatkowo - w pierwszym ze znaczeń - za potocyzm.

26 Użycia o konkretnej referencji wykazują „większą wrażliwość” omawianych rzeczowników na płeć nazywanych nimi osób niż ich użycia predykatywne, natomiast w odniesieniu gatunkowym maskulina mogą oznaczać osoby różnej płci. Szczególnie formy pluralne (w większym stopniu niż singularne) dopuszczają abstrahowanie od płci oznaczanych osób, por. (wszyscy) lutniści/fleciści/harfiści. Zagadnienie statusów referencyjnych analizowanych maskulinów nie jest wszakże przedmiotem niniejszego artykułu. 
grupy społecznej w sposób naturalny, niezależny od jej woli ${ }^{27}$ ), co sugeruje, że można go używać dla nazwania każdej osoby bez względu na płeć, por. np.:

zakonnik c złon ek zakonu (zob. wyżej definicję rzeczownika członek).

Wydaje się jednak, że w odniesieniu do kobiet można użyć jedynie pokrewnej nazwy żeńskoosobowej zakonnica 'członkini zakonu', a więc lepsza byłaby w wypadku rzeczownika zakonnik definicja z użyciem definiensa mężczyzna ${ }^{28}$, por. z definicją rzeczownika synonimicznego:

mnich 1. męż c z y z n a, który żyje we wspólnocie religijnej oddzielonej od reszty społeczeństwa (mnichem nie nazwie się też kobiety, ale użyje się - analogicznie do zakonnicy - rzeczownika mniszka 'c zło n ki n i wspólnoty religijnej oddzielonej od reszty społeczeństwa'29).

\section{Rzeczowniki żeńskoosobowe}

Znaczenia rzeczowników żeńskoosobowych pochodnych od opisanych wyżej rzeczowników męskoosobowych definiowane są - podobnie jak przedstawione wyżej znaczenia rzeczowników męskoosobowych - w różnorodny sposób, ale zawsze ich definicje wskazują na kobiety.

Najczęściej w funkcji konstytutywnego członu definicji tych znaczeń (typ 1) występuje rzeczownik kobieta ('dorosły człowiek płci żeńskiej' ${ }^{30}$ ) i najwięcej jest w tej grupie rzeczowników motywowanych maskulinami, których znaczenia są definiowane za pomocą rzeczownika osoba ${ }^{31}$, por. np.:

chrześcijanka k o bi e ta, która wyznaje chrześcijaństwo $(\leftarrow$ chrześcijanin o s o b a, która wyznaje chrześcijaństwo).

W dalszej kolejności są feminatywy motywowane maskulinami, których definicje znaczeń zawierają rzeczownik mężczyzna lub szczegółową nazwę męskoosobową albo peryfrazy ten, kto i ktoś, kto, por. np.:

(a) rywalka 2. k o bi i t a, która konkuruje z inną kobietą, starając się zdobyć uczucia mężczyzny $(\leftarrow$ rywal 2. męż c zy z n a, który konkuruje z innym mężczyzną, starając się zdobyć uczucia kobiety);

27 Zob. członek w zn. 2 w WSJP PAN.

28 W definicji znaczenia rzeczownika zakonnik, jaką podaje się w USJP, także występuje definiens członek, por. 'c złon e k zakonu męskiego; mnich', wyróżnienie moje - A.S.D.), ale na męską płeć osoby nazywanej zakonnikiem wskazuje określenie rzeczownika zakon: męski.

29 Zob. mniszka w zn. 1 w WSJP PAN.

30 Zob. kobieta w zn. 1 w WSJP PAN.

31 Jak pisze Marek Łaziński, zgodnie ze słowotwórstwem synchronicznym w tradycji Dokulilowskiej podstawami feminatywów nie są odpowiednie męskoosobowe nazwy mężczyzn, ale nazwy oparte semantycznie na pojęciach wyrażanych m.in. rzeczownikiem osoba (por. Łaziński 2006: 246-247), dlatego omawiając sposoby definiowania feminatywów (w całej tej części artykułu), zwracam uwagę na konstytutywne definiensy podstawowych maskulinów, bowiem - jak się okazuje nie zawsze są/mogą to być rzeczowniki osoba/człowiek czy peryfrazy ten, kto/ktoś, kto. 
24 | ARTYKUŁY I ROZPRAWY | J̨̨ZYK POLSKI | CI 3

(b) pięcioboistka kobiet a uprawiająca pięciobój $(\leftarrow$ pięcioboista s p or towi e c uprawiający pięciobój);

(c) przedstawicielka kobi et a, która występuje w imieniu kraju, organizacji lub grupy i jest członkiem tego kraju, tej organizacji lub grupy $(\leftarrow$ przedstawiciel t e n, k to reprezentuje kogoś lub coś);

(d) dawczyni 1. k o b i e ta, która oddaje własne tkanki, narządy lub płyny z organizmu osobie tego potrzebującej $(\leftarrow$ dawca 1 . kt oś, k to oddaje własne tkanki, narządy lub płyny z organizmu osobie tego potrzebującej).

Najmniej jest natomiast w omawianej grupie feminatywów utworzonych od maskulinów, których znaczenia są definiowane za pomocą rzeczownika człowiek, por. np.:

kołtunka pogard. kobiet a ograniczona i mająca wąskie horyzonty intelektualne $(\leftarrow$ kołtun pogard. człowiek ograniczony i mający wąskie horyzonty intelektualne).

Sporadycznie definicyjny rzeczownik kobieta współwystępuje z rzeczownikami dziewczyna ('młoda kobieta, w wieku od kilkunastu do dwudziestu kilku lat'32) i dziewczynka ('dziecko płci żeńskiej ${ }^{33}$ ), wyrażającymi alternatywne (w stosunku do pojęcia kobiety) składniki znaczeń (definicje znaczeń podstawowych maskulinów zawierają w funkcji konstytutywnej rzeczownik osoba), por. np.:

(a) latawica 1. pot. pejorat. k o bi e ta lub d zi e w c z y n a często korzystająca z rozrywek poza domem ( $\leftarrow$ latawiec 2. pot. pejorat. o s o b a często korzystająca z rozrywek poza domem);

(b) psotnica kobieta lub dziewczynka, która robi coś dla żartu, niechcący powodując czasem szkodę lub przykrość $(\leftarrow$ psotnik o s o b a, która robi coś dla żartu, niechcący powodując czasem szkodę lub przykrość).

Można też wskazać przykłady podobnych feminatywów, których znaczenia są definiowane analogicznie do definicji znaczeń odpowiednich maskulinów, por. np.:

(a) druhna dziewczyna lub kobiet a należąca do organizacji harcerskiej;

(b) druh chłopiec lub mężczyzna należący do organizacji harcerskiej ${ }^{34}$.

Rzeczownik dziewczyna występuje również samodzielnie w funkcji definiensa, por. np.: pasterka książk. d zi e w c zy na pilnująca pasących się zwierząt $(\leftarrow$ pasterz 1. o s o b a, która pilnuje pasących się zwierząt).

32 Zob. dziewczyna w zn. 1 w WSJP PAN.

33 Zob. dziewczynka w zn. 1 w WSJP PAN.

34 Podobnie zdefiniowane są też znaczenia cytowanych wyżej maskulinów kolega i wybranek oraz odpowiadających im feminatywów koleżanka (zob. zn. 1 w wSJP PAN) i wybranka. 
Znaczenia nielicznych feminatywów są definiowane za pomocą pojęcia osoby z określeniem jej płci, por. np.:

równolatka 1. o s oba płci żeńskiej, która ma tyle samo lat, co inna osoba $(\leftarrow$ równolatek o s ob a, która ma tyle samo lat co inna osoba) $)^{35}$.

Inny typ członu konstytutywnego definicji znaczeń omawianych feminatywów (typ 2) reprezentują nazwy żeńskoosobowe będące hiponimami rzeczownika kobieta (rzadziej dziewczyna), w tym także hiponimami pośrednimi, por. np.:

caryca 1. mon archin i w dawnej Rosji (zob. monarchini wła d czyn i państwa, zwykle dziedziczna, sprawująca władzę bezterminowo; władczyni 1. k o bi et a, która sprawuje najwyższą władzę w państwie).

Feminatywy tego typu są motywowane rzeczownikami męskoosobowymi, których znaczenia zdefiniowano dwojako:

(1) najczęściej za pomocą rzeczowników pokrewnych konstytutywnemu definiensowi znaczenia rzeczownika żeńskoosobowego i opartych semantycznie na pojęciu ogólnym ('osoba'/'ten, kto'), por. np.:

(a) gimnazjalistka uczennica gimnazjum (zob. uczennica 1. d zi ewczyna, która uczy się w szkole) $<$ gimnazjalista u c z eń gimnazjum (zob. uczeń 1. o s o b a, która się uczy w szkole);

(b) aktorka artystka odgrywająca role w teatrze bądź filmie (zob. artystka 1. ko bi eta, która uprawia określoną dziedzinę sztuki $\leftarrow$ aktor a r ty s t a odgrywający role w teatrze bądź filmie (zob. artysta 1. t e n, kt o uprawia określoną dziedzinę sztuki);

(2) rzadziej bezpośrednio rzeczownikami mężczyzna lub osoba, por. np.:

(a) mniszka 1. c złon kin i zakonu lub wspólnoty religijnej oddzielonej od reszty społeczeństwa (zob. członkini 2. kobi et a należąca do jakiejś organizacji politycznej, naukowej lub społecznej w wyniku osobistej decyzji lub z wyboru $\leftarrow$ mnich 1 . mę ż c z y z n a, który żyje we wspólnocie religijnej oddzielonej od reszty społeczeństwa;

(b) antyfaszystka przeciwn iczka faszyzmu (zob. przeciwniczka 2. k ob i e ta, która uznaje coś za złe i gotowa jest to zwalczać) $\leftarrow$ antyfaszysta o s ob a, która jest przeciwnikiem faszy$\mathrm{zmu}$ - ideologii.

Hiponimem kobiety jest też rzeczownik żona ('k o b i e t a będąca w związku małżeńskim z mężczyzną w stosunku do tego mężczyzny ${ }^{36}$ ), który także wykorzystuje się jako definiens znaczeń odpowiednich feminatywów, por. np.:

35 Warto w tym miejscu zauważyć, że definicję znaczenia synonimicznego do równolatki feminatywu rówieśnica konstytuuje rzeczownik kobieta, a nie wyrażenie osoba płci żeńskiej.

36 Zob. kobieta w wsJP PAN. 
baronowa 1 . ż on a barona - męż c z y z ny z tytułem szlacheckim $(\leftarrow$ baron 1 . mę ż c zy zna, który ma tytuł szlachecki lub nadawany przedstawicielom burżuazji, niższy w hierarchii od tytułu hrabiego) $)^{37}$.

Dodatkowe wskazanie płci osoby, której żona jest nazywana za pomocą definiendum, jakie zawiera definicja rzeczownika baronowa ${ }^{38}$, wydaje się potrzebne w definicjach znaczeń feminatywów pochodnych od rzeczowników, których znaczenia nie wskazują na płeć osób nazywanych tymi rzeczownikami (bowiem definiowane są za pomocą rzeczownika władca, opartego z kolei na znaczeniu rzeczownika osoba: 'o s o b a , która sprawuje najwyższą władzę w państwie ${ }^{39}$ - oba są semantycznie bezpłciowe/dwupłciowe), por. np.:

królowa 2. ż o n a króla $(\leftarrow \text { król 1. koronowany wła d c a państwa, zwykle dziedziczny })^{40}$.

Trzeba w tym miejscu zauważyć, że inaczej zostało zdefiniowane znaczenie pokrewnego feminatywowi królowa rzeczownika królewna - odpowiednia definicja jest realnoznaczeniowa (bez użycia podstawowego rzeczownika $k r o ́ l)^{41}$, por.:

królewna 1. có r k a pary królewskiej,

co różni ją od definicji znaczenia innego feminatywu definiowanego za pomocą rzeczownika córka ('d ziecko płci żeńskiej w stosunku do swoich rodziców’² ), por.:

hrabianka 1. córka hrabiego ${ }^{43}$.

Także porównując definicje leksemów należących do innych pól znaczeniowych (analogicznie do sytuacji wśród rzeczowników męskoosobowych), można zaobserwować niekonsekwentne stosowanie przedstawionych wyżej sposobów definiowania znaczeń rzeczowników żeńskoosobowych (za pomocą rzeczownika kobieta lub jego hiponimów), czego przykładami są następujące grupy feminatywów:

37 Podobnie, ale krócej brzmi definicja znaczenia hrabiny: 'ż o n a hrabiego'.

38 Tu spełnia ono przede wszystkim funkcję wskazującą na odpowiednie znaczenie użytego w definicji rzeczownika baron.

39 Zob. władca w zn. 1 w wsJP PAN.

40 Brak doprecyzowania rzeczownika król rzeczownikiem mężczyzna (króla - mężczyzny) może prowadzić do konstatacji, że królowa może być żoną króla kobiety, skoro królem może być osoba płci żeńskiej, por. definicję innego znaczenia rzeczownika królowa w wSJP PAN: 'kobieta, która sprawuje władzę w państwie jako k ról' (co ciekawe, analogicznego znaczenia nie przypisuje się rzeczownikowi księżna, choć wynika ono z definicji znaczenia rzeczownika książę, por. zn. 1 'niekoronowany wła d c a odrębnego państwa').

41 Podobnie w wypadku rzeczownika księżniczka. Oba rzeczowniki nazywające córki (królewna, księżniczka) są motywowane odpowiednimi rzeczownikami męskoosobowymi, nazywającymi ich ojców, zob. w Jadacka i in. 2001: KRóL I $(\rightarrow$ król-ewna) i KSIĄŻĘ 1. ( $\rightarrow$ księż-niczka). Za pomocą podstawowych maskulinów znaczenia tych feminatywów zostały zdefiniowane w USJP, por. królewna 1. 'córka króla; dawniej też: żona królewicza' i księżniczka książk. 'córka k si ę ci a' (wyróżnienia moje - A.S.D.).

42 Zob. córka w zn. 1 w WSJP PAN.

43 Tak samo w USJP, zob. hrabianka 'córka h r a bi e go' (wyróżnienie moje - A.S.D.). Córka hrabiego jest córką również jego żony, o czym nie mówi się w tej definicji, a co można uznać za przykład niekonsekwencji w sposobie definiowania znaczeń feminatywów podobnych semantycznie. 
(1) nazwy osób płci żeńskiej będących twórcami dzieł pisanych, por. np.:

(a) feminatyw o znaczeniu definiowanym za pomocą rzeczownika kobieta: komediopisarka k o bi e ta, która pisze komedie ${ }^{44}$;

(b) feminatyw o znaczeniu definiowanym za pomocą rzeczownika autorka ('ko b i e t a, która stworzyła jakieś dzieło ${ }^{35}$ ):

dramatopisarka a u to rk a dramatów - utworów literackich przeznaczonych do wystawienia na scenie ${ }^{46}$;

(2) nazwy osób płci żeńskiej zatrudnionych w jakimś miejscu pracy, por. np.:

(a) feminatyw o znaczeniu definiowanym za pomocą rzeczownika kobieta:

bibliotekarka kobi e ta pracująca w bibliotece i zajmująca się gromadzeniem i wypożyczaniem książek;

(b) feminatyw o znaczeniu definiowanym za pomocą rzeczownika pracownica ('k ob i e ta zatrudniona $\mathrm{w}$ jakimś miejscu pracy ${ }^{37}$ ):

aptekarka 1. pra cown i ca apteki, która sporządza i sprzedaje lekarstwa;

(3) nazwy osób płci żeńskiej będących prawnikami, por. np.:

(a) feminatyw o znaczeniu definiowanym za pomocą rzeczownika kobieta:

obrończyni 2. ko bi e ta, która jest upoważniona do obrony interesów oskarżonego w sądzie w sprawie karnej;

(b) feminatyw o znaczeniu definiowanym za pomocą rzeczownika funkcjonariuszka ('ko bi e t a pracująca w służbach państwowych'48):

prokuratorka fu nkcjo nariu szka prokuratury zajmująca się ściganiem przestępstw i pełniąca w sądzie funkcję oskarżyciela;

(4) nazwy osób płci żeńskiej, których własnością jest majątek ziemski, por. np.:

(a) feminatyw o znaczeniu definiowanym za pomocą rzeczownika kobieta w połączeniu $\mathrm{z}$ jego hiponimem właścicielka ( ' $\mathrm{k}$ o bi e ta, do której należy to, co zostało wyrażone następującym rzeczownikiem ${ }^{\text {'49): }}$

ziemianka 1. dawniej kobi eta będąca właścicielką majątku ziemskiego lub żoną właściciela takiego majątku;

44 Podobnie pamiętnikarka.

45 Zob. autorka w zn. 1 w WSJP PAN.

46 Podobnie powieściopisarka.

47 Zob. pracownica w WSJP PAN.

48 Zob. funkcjonariuszka w WSJP PAN.

49 Zob. właścicielka w zn. 1 w WSJP PAN. 
(b) feminatyw o znaczeniu definiowanym za pomocą rzeczownika właścicielka:

dziedziczka 2. właścicielka lub żona właściciela majątku ziemskiego w dawnej Polsce (znaczenie ziemianki można zdefiniować w taki sam sposób, wstawiając w pozycję wyrażenia kobieta będąca właścicielką rzeczownik właścicielk ${ }^{50}$ );

(5) nazwy osób płci żeńskiej należących do zgromadzeń zakonnych, por. np.:

(a) feminatyw o znaczeniu definiowanym za pomocą wyrażenia członkini ('ko bie ta należąca do jakiejś organizacji w wyniku osobistej decyzji lub z wyboru' ${ }^{51}$ ):

franciszkanka członkin i zakonu franciszkanek ${ }^{52}$,

(b) feminatyw o znaczeniu definiowanym za pomocą rzeczownika zakonnica ('c złon kin i zakonu' ${ }^{53}$, zob. wyżej członkini):

bernardynka 1. rel. z a ko n n i c a należąca do katolickiego, żeńskiego zakonu, istniejącego tylko w Polsce, opartego na regule św. Bernarda ${ }^{54}$.

Są też przykłady łączenia wskazanych wyżej dwóch sposobów definiowania znaczeń feminatywów (rzeczownik kobieta + jego hiponim), por. np.:

(a) archeolożka kobieta, która jest spe cjalistką w dziedzinie archeologii $(\leftarrow$ archeolog badacz będący specjal istą w dziedzinie archeologii);

(b) twórczyni 2. k o b i e ta, która jest a u t o r k ą dzieł w określonej dziedzinie sztuki ( $\leftarrow$ twórca 2. a rtyst a będący a u to r e m dzieł w określonej dziedzinie sztuki).

Obie definicje mogłyby być konstytuowane odpowiednio tylko za pomocą definiensów specjalistka i autorka (podobnie jak definicje znaczeń podstawowych maskulinów).

Inny, choć paralelny, sposób definiowania znaczeń rzeczowników żeńskoosobowych przynoszą definicje, w których obok rzeczownika kobieta funkcję definiensa pełni r ze cz o w n i k męskoosobowy:

(1) pokrewny definiendum (będący dla niego podstawą słowotwórczą i definiowany za pomocą rzeczownika osoba), np.:

50 Nie da się też nie zauważyć, że przytoczone definicje znaczeń rzeczowników ziemianka i dziedziczka są złożone - wyłaniają się z nich dwa odrębne znaczenia, a mianowicie: 1. 'właścicielka' i 2. 'żona właściciela' (na ich rozłączność wskazuje zastosowany spójnik lub).

51 Zob. członkini w zn. 2 w wSJP PAN.

52 Podobnie cysterka i karmelitanka, ale ich definicje są rozbudowane i zawierają wiedzę encyklopedyczną, natomiast definicja znaczenia rzeczownika franciszkanka zawiera błąd ignotum per ignotum, por. definiendum franciszkanka i definiens franciszkanek). Poza tym rzeczownik karmelitanka w odróżnieniu od dwóch pozostałych feminatywów jest opatrzony kwalifikatorem religijny (w USJP wszystkie one mają taką kwalifikację).

53 Zob. zakonnica w WSJP PAN.

54 Podobnie benedyktynka i kapucynka, ale definicje ich znaczeń są krótsze, nie zawierają informacji encyklopedycznych. Wszystkie te rzeczowniki zostały uznane w WSJP PAN (podobnie jak w USJP) za terminy religijne. 
sędzina 1. pot. ko bi et a będąca sęd zią (w sądzie $)^{55}(\leftarrow$ sędzia 1a. o s o b a, która zawodowo zajmuje się rozstrzyganiem w imieniu państwa sporów i robi to zgodnie z obowiązującym prawem);

(2) pokrewny definiendum (będący dla niego podstawą słowotwórczą i definiowany za pomocą rzeczownika mężczyzna), np.:

mężatka ko bi et a, która ma męża $(\leftarrow m a ̨ \dot{z} 1$. m ęż c zy z n a będący w związku małżeńskim z kobietą w stosunku do tej kobiety);

(3) niepokrewny definiendum (będący definiensem jego podstawy słowotwórczej i definiowany za pomocą rzeczownika osoba), np.:

anglistka 1a. kobieta, która jest specjalis tą od języka, literatury i kultury angielskiej $(\leftarrow$ anglista 1a. specjalist a od języka, literatury i cywilizacji angielskiej, zob. specjalista 1. o s o b a, która posiadła gruntowną wiedzę lub wysokie umiejętności w jakiejś dziedzinie ${ }^{56}$.

Uwagę zwracają definicje, w których pokrewny definiendum rzeczownik męskoosobowy (jako definiens) jest przydawką definiensa kobieta ${ }^{57}$, jak w wypadku następujących nazw osób płci żeńskiej związanych z wojskowością:

(a) żołnierka 1. kobieta żołnierz - osoba służąca w wojsku;

(b) saperka 1. kobi et a żołn i er z zajmująca się zakładaniem ładunków wybuchowych bądź ich unieszkodliwianiem, a także budową umocnień, dróg i mostów.

Jednakże nie wszystkie znaczenia rzeczowników z tego samego pola znaczeniowego są w taki właśnie sposób definiowane, por. np.:

partyzantka 2. kobiet a walcząca w partyzantce - oddziałach zbrojnych

(tak samo można by zdefiniować znaczenie żołnierki i byłaby to definicja prostsza, bez potrzeby odwoływania się do znaczenia rzeczownika żołnierz, por. 'kobieta służąca w wojsku').

Nie można, na zakończenie, pozostawić niezauważonym sposobu definiowania znaczeń zarówno rzeczowników męskoosobowych, jak i rzeczowników żeńskoosobowych za pomocą synonimów należących do innej odmiany języka niż definiendum (choć pozostaje on na marginesie definicji omówionych wyżej), co jest zgodne z cytowaną wcześniej propozycją definiowania znaczeń ${ }^{58}$, por. np.:

55 Identycznie w WSJP PAN zdefiniowano znaczenie 1 b. rzeczownika sędzia (zob. zakończenie artykułu).

56 Podobnie w wypadku germanistki. Warto porównać definicję znaczenia anglistki z cytowaną wyżej definicją znaczenia archeolożki. Użyto w nich dwóch pokrewnych, ale różniących się rodzajem gramatycznym definiensów: tam specjalistka, tu specjalista.

57 Taki sposób definiowania pojawia się w definicjach znaczeń licznych feminatywów w UsJP, zob. np. choreografka, posłanka, prokuratorka, szefowa, szoferka II, szulerka, złodziejka, żołnierka, a także bohaterka (obok definicji 'kobieta mężna, odważna'). 
(a) frajer pot. now icjus z - o s ob a początkująca, zob. nowicjusz 1. o s ob a nowa w jakimś środowisku, zawodzie lub określonej dziedzinie działalności, niemająca jeszcze doświadczenia;

(b) frajerka pot. nowicjuszka - kobieta początkująca, zob. nowicjuszka 1. książk. k o b i e ta początkująca, niemająca doświadczenia w jakimś zawodzie lub w jakiejś działalności

(rzeczowniki w parach frajer - nowicjusz, frajerka - nowicjuszka różnią się pragmatycznie ${ }^{59}$, a mianowicie: definienda są potoczne, a ich definiensy należą do standardowej odmiany języka; wyrażenia osoba początkująca i kobieta początkująca z jednej strony dodatkowo - choć redundantnie - definiują znaczenia obu definiendów, a z drugiej - co należy uznać za podstawową ich funkcję - wskazują na znaczenie, w jakim użyto (wieloznacznych) definiensów).

\section{Podsumowanie}

Przedstawiony wyżej obraz faktów leksykograficznych dotyczących ujmowania znaczeń maskulinów i pokrewnych/pochodnych feminatywów ukazuje nie tylko problemy definiowania (przede wszystkim w zakresie doboru składnika kategoryzującego definicji), ale także rozbieżność między rzeczywistością leksykalną (znaczeniami zapisanymi w słownikach) a praktyką językową, gdyż użytkownicy języka (szczególnie użytkowniczki) coraz częściej chcą kobiety nazywać odpowiednimi rzeczownikami żeńskoosobowymi (np. dyrektorka szkoły zamiast dyrektor), a nie męskoosobowymi, mimo że słownikowe definicje znaczeń tych ostatnich sugerują, że można je odnosić także do osób płci żeńskiej. Nie tylko różnice między analizowanymi definicjami znaczeń rzeczowników męskoosobowych odnotowanych w obu ekscerpowanych słownikach (WSJP PAN i USJP), ale też porównanie sposobów definiowania znaczeń maskulinów należących do tego samego pola znaczeniowego pokazują, że definicje te mogą budzić wątpliwości (jak np. w wypadku rzeczownika dwudziestolatek - nazwa każdej osoby ${ }^{60}$ czy tylko nazwa mężczyzny ${ }^{61}$ ?) i są (jak się wydaje) bardziej wytworami intuicji ich autorów niż zapisem znaczeń utrwalonych społecznie w systemie językowym. Zatem za podstawowy problem leksykograficzny należy uznać ustalenie, które maskulina są polisemiczne (będąc w pierwszym - podstawowym - znaczeniu rzeczownikami męskoosobowymi tylko formalnie/gramatycznie, w drugim zaś - rzeczownikami męskoosobowymi formalnie i semantycznie), a które nazywają wyłącznie mężczyzn ${ }^{62}$ (feminatywy nie sprawiają takiego

59 „Jednostki tożsame znaczeniowo różnią się od siebie z reguły - jak pisze Maciej Grochowski - pod względem przynajmniej jakiejś jednej innej cechy, na przykład gramatycznej, pragmatycznej czy etymologicznej” (Grochowski 1993: 38). 60 Zob. dwudziestolatek w wSJP PAN: 1. o s ob a która ma 20 lat.

61 Zob. dwudziestolatek w UsJP: a) 'm ęż czy z n a mający dwadzieścia lub więcej lat, ale mniej niż trzydzieści' (wyróżnienie moje - A.S.D.).

62 O tych dwóch typach znaczeniowych rzeczowników męskoosobowych R. Laskowski pisze tak: „rzeczowniki rodzaju męskoosobowego oznaczają albo osoby płci męskiej (mąż, brat, ojciec, mężczyzna), albo częściej (wyróżnienie moje - A.S.D.) mają dwa znaczenia: oznaczają osobę bez względu na płeć (por. W grupie jest dwunastu stude ntów, $w$ tym trzech mężczyzn., Irena jest dobrym fachow cem), albo mężczyzn (W grupie jest dziewięć studentek $i$ trzech studentów)" (Grzegorczykowa i in. 1984: 154). 
kłopotu, bowiem można je stosować tylko do nazwania osób płci żeńskiej ${ }^{63}$ ). Trzeba się też zastanowić, czy rzeczowniki pierwszego typu (o dwóch znaczeniach) nie powinny zawsze posiadać dwóch odrębnych definicji: jednej ogólnej, w której płeć nie będzie specyfikowana, i drugiej - wskazującej na płeć męską nazywanej osoby, analogicznej do definicji znaczenia pochodnego rzeczownika żeńskoosobowego. Znamienny jest w tym kontekście wyraz sędzia, który w zależności od odniesienia można uznać za maskulinum lub feminatyw. Jego znaczenie jako rzeczownika męskoosobowego zostało zdefiniowane jedynie za pomocą definiensa osoba (zob. wyżej), a definicja jego znaczenia jako rzeczownika żeńskoosobowego jest identyczna z definicją synonimicznego feminatywu sędzina w zn. 1 (zob. wyżej), por.:

sędzia 1b. ko bi et a będąca sędzią (w sądzie).

To uzasadnia postulat zdefiniowania w podobny sposób jego znaczenia w odniesieniu tylko do mężczyzn, por.:

sędzia mężc zy z a będący sędzią (w sądzie) ${ }^{64}$.

Źródła

USJP: Uniwersalny słownik języka polskiego PWN, wersja 3.o, red. S. Dubisz, Wydawnictwo Naukowe PWN, Warszawa 2008 (CD).

WSJP PAN: Wielki stownik języka polskiego PAN, red. P. Żmigrodzki (online: https://www.wsjp.pl/, dostęp: 28 października 2020).

Bibliografia

Breza E. 2013: Wola Pani Minister nie stworzy formy ministra w polszczyźnie, [w:] M. Milewska-Stawiany, E. Rogowska (red.), Mówię, więc jestem. Rozmowy o współczesnej polszczyźnie, Wydawnictwo Uniwersytetu Gdańskiego, Gdańsk, s. 70-73.

Dyszak A.S. 2013: Potrzeba czy zbędna moda?, [w:] M. Milewska-Stawiany, E. Rogowska (red.), Mówię, więc jestem. Rozmowy o współczesnej polszczyźnie, Wydawnictwo Uniwersytetu Gdańskiego, Gdańsk, s. 78-83.

Dyszak A.S. 2016: Formacje żeńskoosobowe w najnowszych słownikach definicyjnych języka polskiego, [w:] E. Rogowska-Cybulska i E. Badyda (red.), Słowotwórstwo języka mówionego i pisanego. Materiały siódmej konferencji językoznawczej poświęconej pamięci Profesora Bogusława Krei, Wydawnictwo Uniwersytetu Gdańskiego, Gdańsk, s. 127-146.

Dyszak A.S. 2020: O trzech stuletnich feminatywach, [w:] K. Wojan (red.), Wokół pewnego cytatu, BEL Studio, Warszawa, s. $79-85$.

Grochowski M. 1993: Konwencje semantyczne a definiowanie wyrażeń językowych, Polskie Towarzystwo Semiotyczne, Warszawa.

Grzegorczykowa R., Laskowski R., Wróbel H. (red.) 1984: Gramatyka współczesnego języka polskiego. Morfologia, Państwowe Wydawnictwo Naukowe, Warszawa.

63 R. Laskowski, pisząc, że „rzeczowniki osobowe rodzaju żeńskiego oznaczają z a ws z e (wyróżnienie moje - A.S.D.) również żeński rodzaj naturalny” (Grzegorczykowa i in. 1984: 154), wskazał na dwa wyjątki: rzeczownik osoba (będący definiensem wielu omówionych tutaj maskulinów) i rzeczownik postać.

64 Oba rzeczowniki wskazujące jednoznacznie na płeć osoby będącej sędzią (ten sędzia i ta sędzia) są pochodne (choć bez formalnych wykładników tej pochodności) od rzeczownika sędzia w pierwszym znaczeniu. Podobnie np. ten wojewoda i ta wojewoda ( $\leftarrow$ wojewoda 'osoba'), ale w WSJP PAN wojewoda jedynie z definicją znaczenia konstytuowaną przez rzeczownik przedstawiciel (zob. tam wojewoda w zn. 1). 
Jadacka H., Bondkowska M., Burkacka I., Grabska-Moyle E., Karpowicz T. (red.) 20o1: Słownik gniazd słowotwórczych współczesnego języka ogólnopolskiego. Gniazda odrzeczownikowe, Universitas, Kraków.

Kita M. 2013: Preferuję: pani ministro. Dyskusja na temat ministry, [w:] M. Milewska-Stawiany, E. Rogowska (red.), Mówię, więc jestem. Rozmowy o współczesnej polszczyźnie, Wydawnictwo Uniwersytetu Gdańskiego, Gdańsk, s. 88-93.

Łaziński M. 2006: O panach i paniach. Polskie rzeczowniki tytularne i ich asymetria rodzajowo-plciowa, Wydawnictwo Naukowe PWN, Warszawa.

Nowosad-Bakalarczyk M. 2009: Płeć a rodzaj gramatyczny we współczesnej polszczyźnie, Wydawnictwo Uniwersytetu Marii Curie-Skłodowskiej, Lublin.

Saloni Z., Świdziński M. 1985: Składnia współczesnego języka polskiego, Państwowe Wydawnictwo Naukowe, Warszawa.

Zieniukowa J. 2013, „Pani Marszałkini” - czyli o językowym dziwolagu, [w:] M. Milewska-Stawiany, E. Rogowska (red.), Mówię, więc jestem. Rozmowy o współczesnej polszczyźnie, Wydawnictwo Uniwersytetu Gdańskiego, Gdańsk, s. $140-142$.

Summary

\section{Personal-masculine nouns and personal-feminine nouns. Glosses for lexicographic practice}

Keywords: masculine nouns, feminative nouns, meaning range, dictionary definition, definiens.

This article focuses on dictionary definitions of meanings of personal-masculine nouns and personal-feminine nouns motivated by masculine nouns. The definitions contained in the Wielki słownik języka polskiego PAN were analyzed, which, depending on the need, are compared with the relevant definitions in the Uniwersalny stownik jezzka polskiego, and the observations made in this regard constitute the title glosses to the lexicographic practice. The meanings of personal-masculine nouns that do not (primarily) indicate the gender of the people they call are defined in two ways: either by the definiens of the most general meaning (e.g. osoba 'a person'), or by the hyponym of it (e.g. członek 'a member'). In definitions of meanings which suggest that the defined masculine nouns can only be applied to male persons, the noun mężczyzna ('a man') always appears as a definiens. Definitions of meanings of feminine-personal nouns always point to women: either by the noun kobieta ('a woman') or by its hyponym (e.g. autorka 'an authoress'). Comparing the definitions of the meanings of lexemes belonging to the same semantic fields (and also in both of the above-mentioned dictionaries), one can observe an inconsistent use of the presented methods of defining both masculine nouns and feminative nouns. The basic lexicographic problem is finding out which personal-masculine nouns are polysemic (they name people regardless of gender and only men), and which name only men. 